\author{
Danuta Piróg \\ Uniwersytet Pedagogiczny \\ im. Komisji Edukacji Narodowej \\ w Krakowie
}

\title{
Absolwenci szkół wyższych na rynku pracy w warunkach kryzysu ${ }^{1}$
}

\section{Higher education graduates on the labour market in times of an economic crisis ${ }^{2}$}

\begin{abstract}
Streszczenie
Przechodzenie nowo promowanych absolwentów szkół wyższych z etapu edukacji do etapu zatrudnienia wydaje się być jednym z bardziej złożonych mechanizmów zachodzących obecnie na rynku pracy. Procesy transformacji zaowocowały tendencją do wzrostu korelacji między ukończonym szczeblem edukacji a pozycją na rynku pracy, co ukształtowało w społeczeństwie trwałe przekonanie, że legitymowanie się posiadaniem studiów wyższych jest gwarancją zatrudnienia zgodnego z poziomem wykształcenia i na korzystnych warunkach płacowych. Tymczasem w Polsce i w wielu innych krajach Europy obserwuje się stały wzrost odsetka osób bezrobotnych z wyższym wykształceniem. Celem opracowania jest przedstawienie dynamiki zmian liczby i struktury kierunkowej absolwentów szkół wyższych w latach 1990-2010, ukazanie konsekwencji tych przemian w zakresie pozyskiwania zatrudnienia przez absolwentów oraz próba nakreślenia możliwości optymalizowania ich pomyślnej tranzycji na rynek pracy. Przeprowadzone badania pozwoliły ustalić, że pozycja absolwentów szkół wyższych w Polsce na rynku pracy stopniowo się pogarsza. Podstawowymi drogami optymalizacji ich sytuacji są prowadzenie ilościowych i jakościowych badań tranzycji absolwenckich, reorientacja celów i metod kształcenia akademickiego i realizowanie koncepcji uniwersytetu przedsiębiorczego, uwzględniającej wnioski z przeprowadzonych badań tranzycyjnych.
\end{abstract}

\begin{abstract}
The transition of university graduates from the stage of education to employment seems to be one of the most complex and difficult processes taking place on the labour market. Economic transformation resulted in the tendency to have a correlation between the level of education and ones position on the labour market. This formed the strong belief in society that higher education graduating can guarantee profitable employment relevant to ones level of education. Meanwhile in Poland and in other European countries there has been a constant increase in the percentage of unemployed people with higher education The purpose of the research firstly is to present the dynamic of the number and specialisation of higher education graduates between the years 1990-2010; secondly to show the consequences of these changes regarding the procurement of jobs by the graduates and thirdly attempts at pin-pointing the possibilities of optimising their successful transition into the labour market. The conducted research has proven that the situation of higher education graduates on the labour market in Poland is steadily worsening. The afore-mentioned ways of optimising their situation is conducting qualitative and quantitative surveys of the transition process and implementing the results of these surveys into the conception of an entrepreneurial university.
\end{abstract}

Słowa kluczowe: absolwent; bezrobocie; studia wyższe; rynek pracy; tranzycja

Key words: graduate; higher education; labour market; transition; unemployment

\footnotetext{
${ }^{1}$ Praca naukowa finansowana ze środków budżetowych na naukę w latach 2010-2012 jako projekt badawczy nr N N114 076739.

${ }^{2}$ Study financed from budget funds for science between 2010 and 2012 as research project No. N N114 076739 .
} 


\section{Wprowadzenie}

Zmiany związane z powstawaniem gospodarki opartej na wiedzy zdeterminowały powszechne przekonanie, że w warunkach globalizacji i integracji nakłady na wykształcenie są jedną z najefektywniejszych form inwestycji. Zarówno w teorii ekonomii, jak i w rzeczywistości gospodarczej paradygmat budowania kapitału edukacyjnego jako stymulatora rozwoju regionów oraz państw staje się czynnikiem determinującym tempo i poziom rozwoju gospodarczego, a także jest zasadniczym narzędziem w walce z kryzysem (Borowiec, 2008; Kukliński, 2003; Jakubowska, Rosa, 2011; Zioło, 2008). Ujawniona w okresie transformacji ogólna tendencja do wzrostu korelacji między wykształceniem a pozycją na rynku pracy, charakterystyczna dla gospodarek rynkowych, oraz popularność koncepcji gospodarki opartej na wiedzy ukształtowały w społeczeństwie bardzo mocne przekonanie, że ukończenie studiów wyższych jest niezbędnym warunkiem pozyskania atrakcyjnej pracy, a w skrajnych okolicznościach przynajmniej stanowi gwarancję jakiegokolwiek zatrudnienia (Domański, 2004). Nadto, jak zakłada teoria sygnalizacji, wykształcenie potwierdzone dyplomem ukończenia studiów pełni funkcję jednego z głównych kryteriów rekrutacji i selekcji kandydatów do pracy, bowiem informuje o prawdopodobnie wysokim poziomie posiadanych przez nich kompetencji (Gębski, 2009). Dynamiczny wzrost zainteresowania młodzieży podejmowaniem studiów wyższych był również wynikiem oczekiwania szeregu innych potencjalnych korzyści ekonomicznych, społecznych i podmiotowych, tak w sferze prywatnej, jak w sferze publicznej, płynących z tytułu posiadania dyplomu. Wśród nich kluczową grupę profitów stanowią te, które zwiększają prawdopodobieństwo pozyskania zatrudnienia na korzystnych warunkach płacowych, co w efekcie sprzyja zgromadzeniu większych oszczędności, osiągnięciu wyższej stopy życiowej i statusu społecznego, a także osobistej oraz zawodowej mobilności (ryc. 1).

Ryc. 1. Wybrane potencjalne korzyści płynące z posiadania wyższego wykształcenia


Źródło: opracowanie własne na podstawie Buchner-Jeziorska (2011); Zarycki (2009). 
Należy także mieć na względzie, że w Polsce przez wiele lat ukończenie uczelni wyższej miało wysoką wartość kulturową, było przepustką do kręgu inteligencji i w zdecydowany sposób podnosiło możliwości wykonywania pracy o dużym prestiżu społecznym (Kobylarek 2004). Tym rozlicznym oczekiwaniom i wyzwaniom powinny starać się sprostać uczelnie wyższe (zwłaszcza publiczne), będące szczególnym przypadkiem instytucji, w których ważną rolę odgrywają wartości wyższe i misja społeczna. Model, rola, zasady funkcjonowania uniwersytetu zmieniały się w czasie. Obecnie zachodzi proces kolejnej transformacji wizji uniwersytetu po to, by odpowiadał on wymogom współczesnych realiów, w tym przygotowywał studentów do pomyślnego wejścia na rynek pracy i nie tracił swojego akademickiego charakteru (Leja, 2008). Jednak kształcenie wyższe pojmowane jako inwestycja w kapitał ludzki z poczynioną nadzieją określonych korzyści materialnych i pozamaterialnych jest obarczone ryzykiem (Kryńska, 2011). Zakładanie, że strategia ta musi być efektywna, jest absolutyzowaniem i upraszczaniem. Mimo to społeczeństwo polskie nadal uważa, że warto się kształcić a motywem determinującym podejmowanie trudu edukacji na poziomie wyższym jest oczekiwanie pozyskania atrakcyjnego zatrudnienia po jej zakończeniu. Jak wynika z badań CBOS z 2009 r., średnio 85\% Polaków pragnie wyższego wykształcenia dla swoich dzieci (86\% dla córki i $84 \%$ dla syna, co stanowi wzrost odpowiednio o $22 \%$ i $19 \%$ w porównaniu z badaniami z roku 1993). Głównym motywem dążenia do zdobywania wyższego wykształcenia są spodziewane wysokie zarobki (64\%), ciekawy zawód (39\%) i łatwiejsze życie (35\%) (CBOS, 2009). Tymczasem w Polsce i w wielu innych krajach Europy obserwuje się wzrost odsetka osób bezrobotnych z wyższym wykształceniem.

Sytuacja absolwentów szkół wyższych na rynku pracy, szczególnie trudności związane z pozyskaniem przez nich zatrudnienia po zakończeniu edukacji akademickiej to problem złożony i mający wielorakie uwarunkowania, będące w sferze zainteresowań naukowych specjalistów z różnych dyscyplin (por. m.in.: Buchner-Jeziorska, 2008; 2011; Kabaj, Jeruszka, 2009; Korpysa, 2003; Mikuła-Bączek, 2009; Kiersztyn, 2011, Orczykowska, 2006; Kryńska, 2002, 2008, 2011; Knapińska, 2008; 2009; Jeruszka, 2011; Jakubowska, Rosa, 2011; Sztanderska, Minkiewicz, Bąba, 2005, Piróg, 2011a; 2012a).

Niniejsze opracowanie ma na celu przedstawienie dynamiki zmian liczby i struktury kierunkowej absolwentów szkół wyższych w latach 1990-2010, ukazanie konsekwencji tych przemian w zakresie pozyskiwania zatrudnienia, zwłaszcza przez nowo promowanych absolwentów, i próba nakreślenia możliwości optymalizowania ich pomyślnego przejścia z etapu studiowania do etapu zatrudnienia.

\section{Dynamika liczby absolwentów szkół wyższych}

W okresie 1990-2010 obserwuje się w Polsce stały i dynamiczny wzrost liczby studentów, a zatem i absolwentów szkół wyższych (por. ryc. 2). W roku akademickim 1990/1991 edukację na poziomie wyższym ukończyło 56078 osób. W interwale 6 lat nastąpiło podwojenie liczby absolwentów do 115868 osób (1996/1997), a kolejne podwojenie zajęło już tylko 3 lata (1999/2000; 215423 absolwentów). Do zaspokajania rosnących aspiracji edukacyjnych i przyspieszenia tempa wzrostu liczby absolwentów w znacznej mierze przyczyniło się umożliwienie przez ustawę o szkolnictwie wyższym tworzenia szkół niepublicznych, co zintensyfikowało rozwój sieci instytucji w ramach sektora edukacji wyższej. Działalność uczelni niepublicznych zaowocowała jeszcze szybszym wzrostem liczby studentów, a tym samym i absolwentów. W roku akademickim 1997/1998 wypromowały one swoich pierwszych absolwentów w liczbie 22 625, a w roku 2001/2002 odnotowano już 103712 absolwentów tych szkół, co stanowiło pięciokrotny wzrost w okresie zaledwie trzech lat. W roku 2010/2011 uczelnie niepubliczne ukończyło 169039 studentów. Na przełomie wieków odnotowano naj- 
większy w całym omawianym okresie wzrost liczby absolwentów studiów wyższych (liczba absolwentów w roku akademickim 2000/2001 wyniosła 303966 osób, tj. o 41\% więcej niż w roku poprzedzającym). Istotną przyczyną najpierw tak dynamicznego wzrostu liczby studentów, a potem absolwentów studiów wyższych było także wejście na rynek edukacji akademickiej osób urodzonych w okresie wyżu demograficznego lat 70. XX w. Trend stałego wzrostu liczby absolwentów w XXI w. utrzymał się, a przekroczenie czterystu tysięcy nastąpiło w roku 2006/2007 (410 107 osób). Obecnie liczba ta wynosi 478916 (rok 2009/2010) (GUS, 1990-2010; GUS, 2004-2010).

Ryc. 2. Absolwenci szkół wyższych w latach 1990-2010 (w tys.)

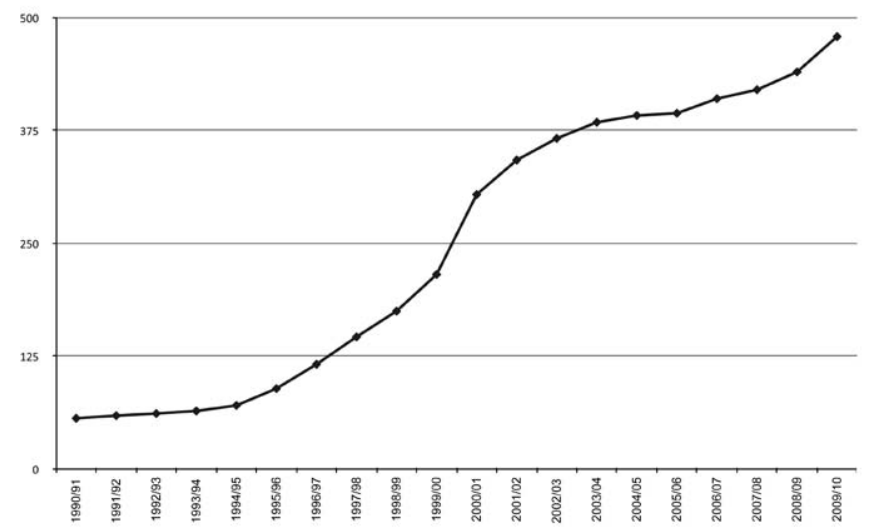

Źródło: opracowanie własne na podstawie: GUS (1990-2003); Szkoły (2004-2010).

Wyrazem rozbudzonych aspiracji edukacyjnych Polaków połączonym z urynkowieniem szkolnictwa wyższego, zwiększaniem limitów rekrutacyjnych i rozpowszechnieniem studiów niestacjonarnych, był gwałtowny wzrost współczynnika skolaryzacji. W latach 1990-2010 współczynniki skolaryzacji wzrosły ponad czterokrotnie, w tym współczynnik skolaryzacji brutto wzrósł z 12,9\% w roku akademickim 1990/1991 do 53,8\% (2010/2011), a netto - odpowiednio z $9,8 \%$ do $40,8 \%$ (por. ryc. 3 ).

Ryc. 3. Współczynnik skolaryzacji brutto w szkolnictwie wyższym w Polsce w latach 1990-2010 (w \%)

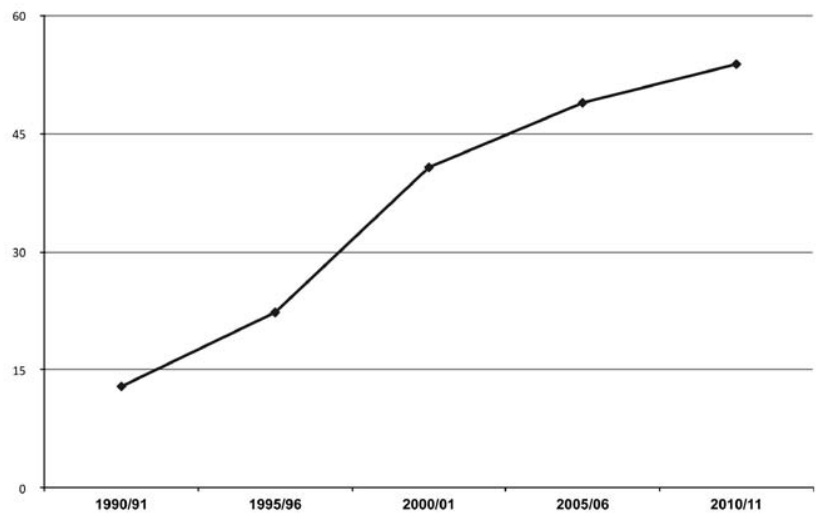

Źródło: opracowanie własne na podstawie: GUS (1990-2000; 2004-2010). 
Obecnie Polska należy do grupy tych państw Unii Europejskiej, w których notuje się jedną z najwyższych liczb studentów na 10 tys. mieszkańców (zajmuje piąte miejsce ze wskaźnikiem 568). Wyższe wskaźniki są tylko na Litwie, w Finlandii, Słowenii oraz na Łotwie (GUS, 2010). Kształcenie stało się sposobem dostosowania się młodzieży do obserwowanych zmian na rynku pracy. Podnoszenie poziomu wykształcenia było też inspirowane przez działania podmiotów polityki edukacyjnej w dziedzinie szkolnictwa publicznego, stałe podnoszenie dostępności i poszerzanie oferty edukacyjnej (kierunkowej i specjalnościowej).

\section{Zmiany kierunkowe}

Wpływ na sytuację absolwentów wchodzących na rynek pracy, oprócz zaprezentowanego dynamicznego wzrostu ich liczby, ma również tryb, kierunek i stopnień ukończonych studiów. W omawianym okresie zwiększyła się liczba uczelni wyższych, a w ich obrębie gama kierunków i specjalności do wyboru, zatem i struktura kierunkowa absolwentów wykazywała wyraźne trendy zmian.

W roku akademickim 1990/1991 najliczniejszą zbiorowość stanowili absolwenci kierunków technicznych (19,4\% ogółu absolwentów szkół wyższych), wyprzedzając absolwentów kierunków pedagogicznych (17,5\%), kierunków medycznych (10,1\%), kierunków związanych z biznesem i zarządzaniem $(9,8 \%)$ oraz kierunków humanistycznych $(9,6 \%)$. Odsetek osób $\mathrm{z}$ dyplomem ukończenia studiów technicznych był jednak stosunkowo niski w porównaniu z rokiem 1980/1981, kiedy stanowili oni około 32\% ogółu. Od początku lat 90. XX w. rosnącą popularnością cieszyły się kierunki z zakresu biznesu, finansów, bankowości, zarządzania oraz nauki społeczne i prawo. W następnej dekadzie, od w roku akademickiego 2000/2001, w strukturze absolwentów dominowali już ekonomiści $(33,7 \%)$. Na drugiej pozycji niezmiennie plasowały się osoby kończące kierunki pedagogiczne (16,2\%), a trzecie miejsce w hierarchii (14,3\%) należało do absolwentów kierunków społecznych. W roku 2005/2006 także dominowali absolwenci kierunków ekonomicznych i administracyjnych $(27,1 \%)$, a tuż za nimi najliczniejszą, choć nieco mniejszą niż pięć lat wcześniej, zbiorowość stanowili absolwenci uczelni pedagogicznych (15,6\%). Trzecie miejsce zajęli absolwenci kierunków społecznych $(14,7 \%)$, a za nimi uplasowali się absolwenci kierunków humanistycznych $(8,4 \%)$ oraz inżynieryjno-technicznych $(5,4 \%)$. W XXI w. zmiany struktury kierunkowej wiodących grup absolwentów były znacznie mniejsze. Utrzymywała się przewaga (choć z malejącym odsetkiem) absolwentów profilów ekonomicznych i administracyjnych (z 31,5 \% w roku 2000 do 25,7\% w roku 2010). Drugie miejsce nadal należało do kierunków pedagogicznych, natomiast trzecie zajęli absolwenci kierunków społecznych. Tuż za nimi znaleźli się absolwenci kierunków humanistycznych. W ostatnim dziesięcioleciu największy, bo trzykrotny wzrost, zarejestrowano wśród absolwentów kierunków medycznych (z 2,3\% w 2000 do 6,9\% w roku 2010) (GUS, 2004-2010).

Obecnie w Polsce przypada średnio 11,1 absolwenta kierunków przyrodniczych i technicznych na 1000 mieszkańców, przy średniej dla krajów UE na poziomie 12,9. Szczególnie niepokojący jest obserwowany trend spadkowy zainteresowania studiami na kierunkach inżynieryjno-technicznych.

Różnice w proporcjach absolwentów poszczególnych kierunków były i są efektem oddziaływania wielu czynników. Do ważniejszych zaliczyć należy zmiany popytu na rynku pracy, wynikające m.in. z ograniczenia produkcji przemysłowej, restrukturyzacji przemysłu, pojawienia się nowych typów przedsiębiorstw korporacyjnych, rozwoju instytucji finansowych, banków i giełdy. Spadek zainteresowania studiami technicznymi jest także pokłosiem likwidacji obligatoryjnego egzaminu maturalnego z matematyki (Buchner-Jeziorska, 2011: 25). 
Duży popyt ze strony kandydatów na studia ekonomiczne miał swoje korzenie w latach 90 . XX w., kiedy w Polsce rodziła się gospodarka rynkowa, która generowała zapotrzebowanie na specjalistów z tych dziedzin i zapewniała im intratne posady. Na zainteresowanie przyszłych studentów szybko odpowiedział rynek usług edukacyjnych i właśnie uczelni ekonomicznych dotyczył najwyższy dziewiętnastokrotny wzrost ich liczby (z 5 w roku 1990 do 95 w roku 2006/2007) (Mikuła-Bączek, 2009). Drugim, poza popytem na studia ekonomiczne, powodem tak spektakularnego zwiększenia liczby szkół wyższych, oferujących studia ekonomiczne i humanistyczne, był aspekt kosztów. Prowadzenie tych kierunków nie wymagało tak wysokich nakładów finansowych, jak prowadzenie studiów z grupy nauk eksperymentalnych, technicznych, które wiążą się z koniecznością posiadania specjalistycznej aparatury i zaplecza laboratoryjnego. Powodowało to wyraźnie mniejszą aktywność w zakresie uruchomiania takich kierunków przez uczelnie niepubliczne (Borowiec, 2011). Tymczasem kierunki ekonomiczne były i nadal są prowadzone na niemal wszystkich typach uczelni, w tym na uczelniach rolniczych, technicznych, a nawet na wychowania fizycznego.

Wyrazem działań ministerialnych, mających na celu korygowanie zanotowanej dysproporcji pomiędzy absolwentami kierunków humanistycznych a osobami kończącymi studia techniczne i matematyczno-przyrodnicze, było rozpoczęcie przez Ministerstwo Nauki i Szkolnictwa Wyższego dotowania tzw. kierunków zamawianych. Uczelnie, które prowadzą te kierunki studiów, mogą otrzymywać dodatkowe fundusze celem podnoszenia atrakcyjności kształcenia m.in. przez organizowanie dla studentów np. kursów wyrównawczych z matematyki i fizyki, rozbudowanych lektoratów z języka angielskiego, obozów naukowych, zajęć dydaktycznych prowadzonych przez wybitnych specjalistów z różnych dziedzin, kursów dających dodatkowe kwalifikacje i uprawnienia zawodowe, wyjazdów studyjnych do przedsiębiorstw oferujących zatrudnienie absolwentom. Na kierunkach tych wypłacane są dość wysokie motywacyjne stypendia dla studentów. W roku akademickim 2011/12 do kierunków zamawianych zaliczono: analitykę gospodarczą, automatykę i robotykę, elektronikę, i telekomunikację, informatykę, biotechnologię, budownictwo, chemię, energetykę, energetykę jądrową, fizykę i fizykę techniczną, informatykę, informatykę stosowaną z komputerową nauką o materiałach, inżynierię gospodarczą i wodną, inżynierię materiałową, inżynierię środowiska, nanotechnologię i technologię procesów materiałowych, matematykę, mechanikę i budowę maszyn, mechatronikę, ochronę środowiska, studia matematyczno-przyrodnicze, technologie ochrony środowiska, wzornictwo oraz zaawansowane materiały i nanotechnologie (Ministerstwo Pracy i Polityki Społecznej, 2012). Trudno ocenić, czy kwalifikacje nabywane przez studentów na kierunkach zamawianych, są tymi, które znacznie podnoszą konkurencyjność w procesie pozyskiwania zatrudnienia, bowiem nie ma opublikowanych badań sytuacji absolwentów - przedstawicieli tych kierunków na rynku pracy.

W rozpatrywanym okresie nastąpiły także duże zmiany w systemie organizacji studiów. Od 1991 r. wiele wyższych uczelni zaczęło różnicować jednolity, magisterski system studiów. Działania te zostały zintensyfikowane w roku 2005, kiedy ustawowo wprowadzono podział studiów na trzystopniowe. Jak podkreślają U. Sztanderska, B. Minkiewicz i M. Bąba, to właśnie zmiany charakterystyk (tak indywidualnych, jak i zbiorowych) osób z wyższym wykształceniem są czynnikiem mającym istotny wpływ na trudności w pozyskaniu pracy przez absolwentów uczelni wyższych. Ich zdaniem, istnieje duże prawdopodobieństwo, że dzisiejszy absolwent odbył krótszą edukację akademicką niż jego kolega sprzed kilkunastu lat, często w trybie niestacjonarnym, co łączy się z przede wszystkim ze skromniejszym wymiarem godzin dydaktycznych. W tych warunkach kapitał edukacyjny absolwentów jest obecnie znacznie mniejszy i stawia ich w trudniejszym położeniu w procesie konkurowania o pracę (Sztanderska i in. 2005a, b). 
Obecnie zbiorowość absolwencką szkół wyższych tworzą osoby posiadające tytuł doktora, magistra, licencjata, inżyniera, absolwenci studiów stacjonarnych i niestacjonarnych, odbytych tak w dużych ośrodkach akademickich i na renomowanych uczelniach, jak i w szkołach nowo powstałych, często z ubogim doświadczeniem naukowo-dydaktycznym i utrudnionym kontaktem z najlepszymi specjalistami czy bibliotekami (Orczykowska, 2006). Co istotne, w przeciwieństwie do innych krajów, w Polsce tytuł licencjata nie jest ciągle powszechnie uznany za dowód pełnowartościowego wyższego wykształcenia (Teichler, 2011). Ta heterogeniczność zbiorowości absolwentów, połączona z brakiem ogólnopolskich badań ich rzeczywistej sytuacji na rynku pracy, poważnie utrudnia, a niekiedy wręcz uniemożliwia wykonanie jednoznacznej oceny, czy, a jeżeli tak, to który tryb i stopnień ukończonych studiów w obrębie danego kierunku, ułatwia uzyskanie pracy po ich zakończeniu.

\section{Absolwent w dobie kryzysu gospodarczego}

Scharakteryzowany we wcześniejszej części opracowania dynamiczny wzrost liczby absolwentów szkół wyższych zachodził w okresie powiększającego się w Polsce bezrobocia. Na początku badanego okresu bezrobocie w Polsce wynosiło 6,5\% i bardzo szybko zaczęło wzrastać, by osiągnąć swoje maksymalne wartości w latach 2002-2004 (stopa bezrobocia wyższa niż 20\%). Ten niekorzystny trend nie pozostawał bez wpływu na absolwentów uczelni wyższych i chociaż wykształcenie akademickie stanowiło niewątpliwy atut na rynku pracy, to można stwierdzić, że sytuacja tej zbiorowości osób ulegała powolnemu pogorszeniu, a odsetek osób bezrobotnych posiadających wyższe wykształcenie wzrósł z 2,6\% w roku 2000 do 10,5\% w roku 2011 (por. ryc. 4). Na końcu sierpnia roku 2012 różnica między stopą bezrobocia ogółem a stopą bezrobocia wśród osób z wyższym wykształceniem wynosiła zaledwie 1,1 punktu procentowego na korzyść tej zbiorowości osób.

Ryc. 4. Stopa bezrobocia w latach 1999-2012 (w \%)

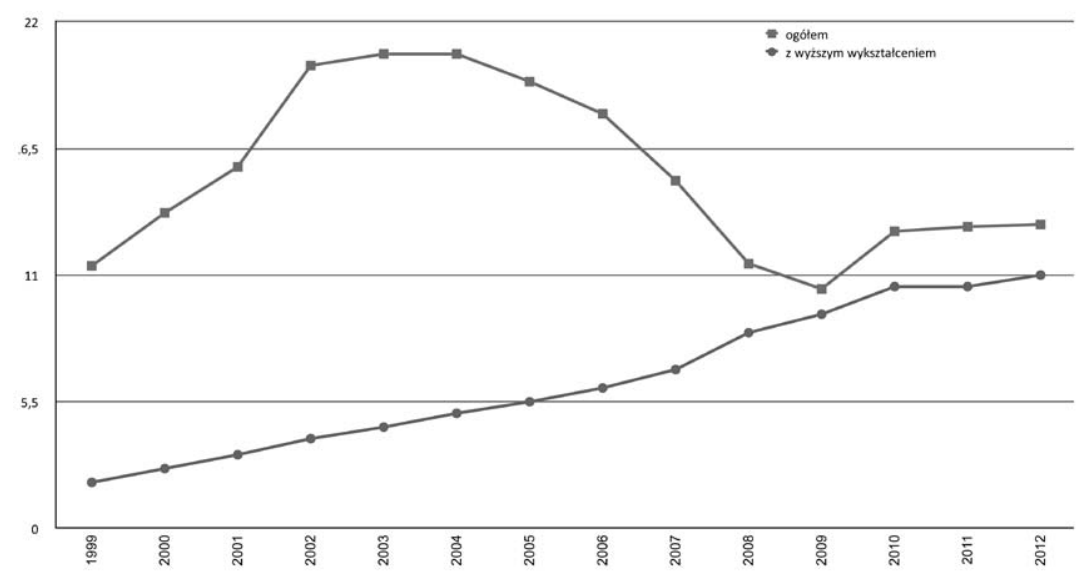

Źródło: opracowanie własne na podstawie GUS (2012).

Podobnie niepokojąco nasilają się trudności z płynnym przejściem na rynek pracy nowo promowanych absolwentów szkół wyższych, które coraz częściej jest obarczone ryzykiem niepowodzenia. W IV kwartale 2010 r. absolwenci studiów wyższych stanowili 36,3\% ogółu absolwentów i 16,3\% wszystkich bezrobotnych absolwentów. W ostatnim dziesięcioleciu 
odsetek bezrobotnych absolwentów z wyższym wykształceniem był niższy niż średnia stopa bezrobocia dla absolwentów ogółem, niemniej około $20 \%$ z nich pozostawało bez pracy (por. ryc. 5).

Ryc. 5. Bezrobotni absolwenci w latach 2003-2012 (w \%)



Źródło: opracowanie własne na podstawie GUS (2003-2012).

Z drugiej strony utrzymanie wskaźnika zatrudnienia osób z wyższym wykształceniem na prawie tym samym poziomie około $76,6 \%$ przez dwadzieścia lat przy tak dynamicznym wzroście liczby absolwentów szkół wyższych należy uznać za sukces w realizacji funkcji zaspokajania potrzeb rynku pracy (por. ryc. 6). Jednak trzeba pamiętać, że wskaźnik ten nie uwzględnia czy absolwent pracuje na stanowisku zgodnym z poziomem wykształcenia, czy poniżej swoich kwalifikacji. W latach 1999-2008 tylko około połowa (54\%) absolwentów szkół wyższych znalazła zatrudnienie na stanowiskach wymagających wyższego wykształcenia (Jeruszka, 2011: 2).

Ryc. 6. Wskaźnik zatrudnienia osób z wyższym wykształceniem 1992-2011 (w \%)

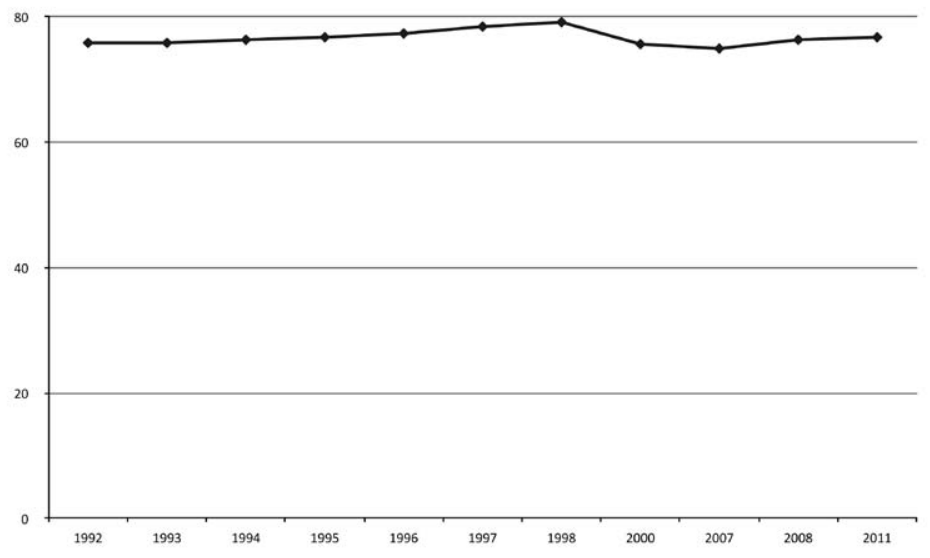

Źródło: opracowanie własne na podstawie Buchner-Jeziorska (2011). 
Obserwowane problemy z pozyskaniem pracy przez absolwentów szkół wyższych były nowym i sprzecznym z powszechnym przekonaniem społeczeństwa procesem. Posiadanie dyplomu ukończenia wyższej uczelni przestało być kluczem do zdobycia atrakcyjnej pracy i skuteczną ochroną przed problemem bezrobocia. Paradoksalnie wskazane zjawiska indukowały dalszy intensywny wzrost liczby studentów i absolwentów, który bywa nazywany nawet swoistą próbą ucieczki młodzieży przed zderzeniem się z wyzwaniami rynku pracy (przynajmniej na okres kształcenia), motywowanej nie tyle nadzieją na zdobycie konkurencyjnych kompetencji w toku studiów na prestiżowej uczelni, co spodziewaną ogólną poprawą sytuacji na rynku pracy i wyciszeniem skutków kryzysu gospodarczego. To z kolei, przez powszechną dostępność szkolnictwa wyższego, przyjmowanie bardzo dużej rzeszy kandydatów na studia niestacjonarne czy na uczelnie niepubliczne, pogorszyło sytuację wszystkich nowych absolwentów studiów wyższych na rynku pracy (Ernst, Young, 2009). Urynkowienie edukacji wyższej spowodowało, że studia mogą podejmować nie tylko osoby o dużych zdolnościach intelektualnych, ale też o walorach przeciętnych i poniżej przeciętnej. Systemy zarządzania uczelnią, głównie w obszarze zapewnienia odpowiedniej jakości, okazały się nieprzygotowane na tak duże zmiany. Efektem tego niekorzystnego trendu jest duża liczba osób legitymujących się dyplomem ukończenia studiów wyższych przy nierzadko jednoczesnym braku realnej zgodności poziomu kompetencji specjalistycznych, psycho-społecznych ze stopniem wykształcenia zapisanym na dyplomie. Niezależnie od chęci i deklaracji werbalnych, uczelnie w znacznym stopniu dopasowały wymagania dydaktyczne do możliwości percepcji odbiorców. Proces ten zdewaluował wartość wyższego wykształcenia i nadszarpnął zaufanie pracodawców wobec kształcenia na tym poziomie (Kryńska, 2011).

Liczba miejsc pracy dla pracowników o wysokich kwalifikacjach i kompetencjach jest znacznie mniejsza niż podaż potencjalnych pracowników. Istnieje duży popyt na pracowników z wyższym wykształceniem, ale głównie na inżynierów i menadżerów projektów. Jednym z dowodów na występowanie nadwyżki, oprócz wzrastającego odsetka bezrobotnych absolwentów szkół wyższych, jest duże i utrzymujące się zapotrzebowanie rynku pracy na pracowników w zawodach nie wymagających ukończenia studiów (pierwsze miejsce i największa liczba wakujących miejsc pracy, tj.: 32,6\% należy do pracowników z wykształceniem zawodowym). Jak podaje raport Ministerstwa Pracy i Polityki Społecznej, najbardziej deficytowe zawody/stanowiska pracy (na podstawie wskaźnika intensywności nadwyżki) w pierwszym półroczu 2011 r. to: ,pozostali praktykujący niekonwencjonalne lub komplementarne metody terapii, czyściciel dywanów, lekarz - rehabilitacja medyczna, pielęgniarka specjalista pielęgniarstwa opieki długoterminowej, pozostali pracownicy domowej opieki osobistej, urzędnik podatkowy ,sprzedawca reklam internetowych, dekorator wyrobów cukierniczych, robotnik osuszania i odgrzybiania budowli, spawacz metodą MIG”. W grupie zawodów o najniższym poziomie wskaźnika intensywności nadwyżki uplasowały się kolejno: ,politolog, technik agrobiznesu, filolog - filologia polska, technik żywienia i gospodarstwa domowego, technik transportu kolejowego, filolog - filologia obcojęzyczna, pozostali pracownicy usług domowych, elektromechanik elektrycznych przyrządów pomiarowych, technik technologii żywności - przetwórstwo mleczarskie, właściciel małego sklepu" (Ministerstwo Pracy i Polityki Społecznej, 2012). W tej sytuacji pracodawca może stawiać absolwentowi nierealne wymagania, bo ma świadomość wysokiej nadwyżki podaży osób z wysokimi kwalifikacjami i nierzadko proponuje niską płacę zasadniczą, mówiąc, że zależy ona od wyników pracy, a mechanizm ich oceny nie jest transparenty (Korpysa, 2003: 126-127).

Ukazane fakty mogą być potwierdzeniem wystąpienia problemu nadwyżki osób z wyższym wykształceniem i nasycenia potrzeb kształcenia na poziomie akademickim w poszczególnych 
kategoriach zawodowych. Wielu absolwentów uczelni wyższych staje zatem przed koniecznością podjęcia zatrudnienia niedopasowanego do poziomu wykształcenia, co niesie ze sobą niepożądane społeczne i indywidualne koszty. Zaliczają się do nich: nakłady finansowe jakie społeczeństwo poniosło na edukację, które w takiej sytuacji są inwestycją przynoszącą straty. Badania wykazały nadto, iż praca poniżej swoich kwalifikacji zmniejsza wydajność pracownika (Kiersztyn, 2011). Kolejnym niekorzystnym następstwem tej nadwyżki jest wypieranie osób z niższym, ale w pełni właściwym w odniesieniu do zadań przewidzianych do realizowania na danym stanowisku, poziomem wykształcenia przez osoby z wyższym wykształceniem, dla których oznacza to pracę na stanowiskach poniżej ich kompetencji i kwalifikacji - tzw brain draining (Jakubowska, Rosa, 2011). Jednym z dowodów na występowanie tego zjawiska, jak wskazują badania POLPAN z lat 1998-2008, jest wzrost odsetka osób z nadwyżką wykształcenia wśród osób pracujących z 7,5\% do 19,1\% (Kiersztyn, 2011: 11).

Przyczyny rosnących trudności wchodzenia na rynek pracy osób kończących studia wyższe są wielorakie. Jedną z nich jest niewątpliwie spadek koniunktury gospodarczej, wynikający z obniżenia popytu globalnego warunkującego popyt na pracę oraz spowolnienie tempa wzrostu gospodarczego (Kryńska, 2000: 7-10). Nadto, trudności te mogą wynikać z odmiennych postaw i oczekiwań tak wśród pracodawców, jak i wśród osób poszukujących zatrudnienia. Do podstawowych czynników zmniejszających szanse zatrudnienia po ukończeniu studiów, a stawianych przez pracodawców zaliczyć można wymagania dotyczące posiadania stażu pracy i znacznego doświadczenia zawodowego. Absolwenci zaś mogą osłabiać swoje szanse na pomyślną tranzycję przez niechęć podejmowania pracy w zawodzie innym niż wyuczony, małą mobilność i brak klarownego planu rozwoju swojej kariery zawodowej.

\section{Kierunki optymalizacji wchodzenia nowo promowanych absolwentów na rynek pracy}

Zarysowany obraz sytuacji absolwentów szkół wyższych na rynku pracy, pokazujący stopniowe osłabienie ich pozycji, wydaje się jasno wskazywać zarówno na potrzebę dyskusji skupiającej się na roli i aktualnych funkcjach szkolnictwa wyższego, jak i na rozpoczęcie konkretnych przedsięwzięć, mających na celu optymalizowanie przechodzenia młodzieży z etapu edukacji do zatrudnienia, określanego jako proces tranzycji (Allen, Van der Velden, 2007) w warunkach kryzysu gospodarczego.

Pierwszym koniecznym krokiem w tym zakresie jest kompleksowe rozpoznanie realnej sytuacji absolwentów szkół wyższych na rynku pracy, zwłaszcza skuteczności procesu ich tranzycji z etapu edukacji do zatrudnienia. Częściowo ten niedoeksplorowany obszar badań powinien być podejmowany przez poszczególne uczelnie, bowiem od października $2011 \mathrm{r}$. Ministerstwo Nauki i Szkolnictwa Wyższego wprowadziło obowiązek monitoringu losów zawodowych absolwentów przez poszczególne uczelnie: art. 13a „uczelnia monitoruje kariery zawodowe swoich absolwentów w celu dostosowania kierunków studiów do potrzeb rynku pracy, w szczególności po trzech i pięciu latach od dnia ukończenia studiów”.

Rodzi się jednak pytanie, czy możliwy będzie dostęp do wszystkich uczelnianych raportów przez osoby i instytucje zainteresowane wynikami takich badań? Jeśli tak, to czy wykonalne będzie porównywanie opracowań, które zrealizowanych z zastosowaniem różnej metodologii i narzędzi badawczych? Wreszcie, czy badanie sytuacji absolwentów na rynku pracy aż po trzech i pięciu latach będzie przydatne uczelniom wyższym do modyfikacji koncepcji programów studiów w czasach, gdy przemiany rynku pracy są niezwykle dynamiczne i indukują potrzebę szybkiego adaptowania się do nowych uwarunkowań? Jeśli celem takich badań ma być dostarczanie uczelniom informacji, które mają służyć im do trafniejszych wprowadzania zmian programowych i metodycznych, wskazane wydaje się być, wzorem rozwiązań przyję- 
tych w większości krajów europejskich, monitorowanie sytuacji nowo promowanych absolwentów krótko po zakończeniu studiów (najczęściej po sześciu miesiącach) i ewentualne ich kontynuowanie po dłuższym czasie (np.: kilku lat).

Drugim obszarem działań powinien być pogłębiony namysł nad współczesnymi koncepcjami kształcenia akademickiego, które służyłyby równie skutecznie realizowaniu swojej tradycyjnej misji i usatysfakcjonowaniu jak najliczniejszej rzeczy interesariuszy. Zasadne wydaje się najpierw przeprowadzenie rzetelnego audytu programu studiów, obejmującego ofertę programową kursów danego kierunku studiów; charakter i intensywność współpracy kierunku studiów z biurem karier uczelni; kontakty z potencjalnymi pracodawcami oraz badanie losów absolwentów na rynku pracy i wykorzystywanie wyników tych badań do korekt programowych (Piróg, 2011b). Następnie wyniki przeprowadzonej oceny należy wykorzystać do reorientacji celów i metod kształcenia akademickiego w obrębie danego kierunku studiów. Jedną z dróg takiej modernizacji jest wkomponowanie w proces dydaktyczny praktycznych metod kształcenia. Szczególną uwagę należy poświęcić metodzie projektów, która na poziomie akademickim powinna być stosowana przede wszystkim jako filozofia konstrukcji całej oferty programowej (Hennemann, Liefner, 2010; Pawson i in., 2006). Wówczas program ma składać się z precyzyjnie wybranych i gruntowanie przemyślanych kursów skupionych na takich problemach do przestudiowania, by umożliwiły doskonalenie krytycznego myślenia, efektywnego rozwiązywania problemów, umiejętności pracy zespołowej i samokształcenia. Sposób postępowania powinien być możliwie najbliższy realnym ścieżkom działań w podobnej sytuacji występującej w życiu i karierze zawodowej przyszłych absolwentów, a prowadzenie niektórych modułów w obrębie kursów tematycznych należy powierzyć praktykom i pracodawcom (Piróg, 2012c).

Ważne wydaje się także posiadanie gruntownej wiedzy studenta każdego kierunku o rynku pracy i umiejętność planowania swojej kariery zawodowej. Znajomość oczekiwań pracodawców, instytucji, które mogą wspierać absolwenta w poszukiwaniu zatrudnienia, podstaw prawa pracy, nabycie umiejętności wyartykułowania swoich zalet, postawienia celów i zaplanowania obszarów dalszego rozwoju zawodowego, może przyczynić się do podjęcia wieloaspektowych działań studentów już w toku studiów, które mogą optymalizować ich szanse na pomyślną tranzycję. Kolejnym niezbędnym etapem jest doskonalenie technik komunikowania się bezpośredniego, pisemnego, elektronicznego i telefonicznego oraz autoreklamy rozumianej jako umiejętność zdefiniowania i promowania własnego potencjału (Piróg, 2012b, c).

Niezwykle istotne jest także wypracowanie dobrego wizerunku danego kierunku studiów oraz marki uczelni. Trwale wysoki poziom kształcenia, wiodące pozycje w rankingach, bogata i ciekawa oferta edukacyjna, której odzwierciedleniem jest poziom kompetencji absolwentów i ich konkurencyjność na rynku pracy, sprzyja większemu zainteresowaniu pracodawców potencjalnymi pracownikami, rekrutującymi się z takich uczelni i kierunków (Dworak, 2011). Na wizerunek znacząco wpływa kadra akademicka, która powinna posiadać zarówno rozległą wiedzę teoretyczną, jak i bogate doświadczenia empiryczne z zakresu prowadzonych zajęć (Kowalska, 2011).

Wszystkie wymienione działania są odpowiedzią na potrzebę kreowania koncepcji uniwersytetu przedsiębiorczego, która zakłada, że szkoła wyższa będzie: „organizacją racjonalnie (twórczo, efektywnie) zarządzającą posiadanym kapitałem społecznym i intelektualnym przez procesy działania specyficzne dla uczelni, to znaczy: badania, kształcenie i kulturotwórcze relacje ze środowiskiem" (Czerepaniak-Walczak, 2010: 58). Celem uczelni jest wówczas pomnażanie kapitału społecznego i intelektualnego, które stanowią zasadniczy czynnik wielowymiarowego rozwoju osobowego. Realizacja tak sformułowanych celów jest możliwa wów- 
czas, gdy dokonana zostanie innowacja metod, form i treści kształcenia akademickiego, które omówiono powyżej. Taka wizja wydaje się również godzić zarówno w niezbywalną potrzebę kontynuowania na jak najwyższym poziomie idei kształtowania elity intelektualnej, jak i prowadzenia nowatorskich, rzetelnych badań naukowych z równoczesnym podjęciem wyzwań wynikających z przemian społeczno-gospodarczych.

Wreszcie, doniosłym kierunkiem optymalizowania szans absolwentów na rynku pracy w warunkach kryzysu jest kształcenie (na wszystkich szczeblach edukacji), mające na celu wypracowanie u młodzieży postaw przedsiębiorczych (Borowiec, Rachwał, 2011; Osuch, 2012; Kurek, Rachwał, 2011; Rachwał, 2006; Tracz, 2006). W kontekście przygotowania do wejścia na rynek pracy przedsiębiorczość należy rozumieć jako podstawę efektywnego zarządzania obszarami życia osobistego, zawodowego i społecznego. Tak postawa w warunkach kryzysu umożliwia zdolność adaptacji do nowych warunków, zwiększa skłonności do zmiany kwalifikacji, miejsca zamieszkania, miejsca zatrudnienia, adaptacji niestandardowych form zatrudnienia, atypowych miejsc pracy, które w zasadniczy sposób podnoszą szanse na płynne przejście na rynek pracy (Kryńska, 2008). Za istotny czynnik wpływający na powodzenie na rynku pracy uznaje się także samoocenę podmiotu jako osoby przedsiębiorczej, która jest kluczem do skutecznej rywalizacji w aktualnych realiach rynkowych (Bernat, Kunasz, 2005).

Można zatem stwierdzić, że działania mające na celu optymalizowanie szans absolwentów na rynku pracy powinny opierać się na trzech filarach: prorynkowych strategiach kształcenia szkół wyższych, proedukacyjnych strategiach pracodawców oraz racjonalnych działaniach studentów.

\section{Zakończenie}

Rozpatrując sytuację absolwentów szkół wyższych na rynku pracy, należy stwierdzić, że jest ona pochodną wielu czynników, do których należy zaliczyć:

- kryzys gospodarczy, który char akteryzuje się zmniejszeniem produkcji, realnych dochodów i wzrostem bezrobocia we wszystkich grupach społecznych,

- ograniczoną zdolność gospodarki do wchłaniania zasobów pracy,

- sytuację demograficzną, zwłaszcza wkraczanie na rynek pracy pokoleń wyżu demograficznego,

- niedostosowanie rozmiarów kształcenia i struktury kierunkowej wybieranych przez młodzież profilów kształcenia do realnych potrzeb rynku pracy,

- malejące wymagania stawiane kandydatom w toku rekrutacji na studia wyższe i w ciągu studiów, umożliwiające zdobycie nominalnie wyższego wykształcenia, ale realnie znacznie odbiegającego od przyjętych standardów,

- dyskryminacyjne rekrutacyjne praktyki pracodawców,

- niedobory w wypracowaniu u przyszłych absolwentów pożądanych postaw sprzyjających skutecznemu poszukiwaniu pracy (Giermanowska, Racław-Markowska, 2003; Skórska, 2004; Sztanderska, 2007).

W świetle przeprowadzonych badań stwierdza się, że ukończenie studiów jest wciąż cennym składnikiem kapitału intelektualnego i stwarza większe szanse na pozyskanie zatrudnienia niż legitymowanie się dyplomami niższych etapów kształcenia. Ze względu na nadwyżkę podaży nad popytem absolwentów większości kierunków studiów muszą się oni jednak wykazywać się coraz wyższą konkurencyjnością, a pracodawcy mogą stosować niemal nieograniczoną selekcję w naborze kandydatów i proponować znacznie mniej korzystne dla pracowników warunki pracy, wyrażone niższym wynagrodzeniem i zatrudnianiem na stanowiskach nie wymagających posiadania dyplomu szkoły wyższej. 
Sytuacja demograficzna Polski, a w konsekwencji - malejący popyt na usługi edukacyjne na poziomie wyższym - powoduje, że zarówno uczelnie o mniejszym prestiżu i krótszych doświadczeniach akademickich, jak i renomowane uniwersytety z tradycjami już zaczynają zabiegać lub w niedalekiej przyszłości będą musiały w sposób szczególny zatroszczyć się o własną pozycję, a niekiedy wręcz dalszą egzystencję na rynku usług edukacyjnych. Należy się spodziewać, że wskaźniki zatrudnialności (podobnie jak w wielu krajach Europy Zachodniej) staną się jedną z miar jakości pracy uczelni i będą współdecydować o jej pozycji na rynku usług edukacyjnych.

Zdecydowana większość szkół wyższych podejmie intensywne działania wykraczające poza dotychczasowe rozwiązania, polegające głównie na tworzeniu nowych kierunków lub specjalności w obrębie tych kierunków. Należy mieć nadzieję, że wiele uczelni będzie intensywnie dążyć do jak najwyższej jakości kształcenia skupionej na wyedukowaniu absolwentów wyposażonych w szeroki zakres kompetencji, które zapewnią im sukces na rynku pracy.

\section{Literatura}

Allen, J., Van der Velden, R. (2007). Transitions from higher education. W: U. Teichler (red.), Careers of University Graduates. Springer, 55-78.

Bernat, T., Kunasz, M. (2005), Realia gospodarcze a postawy przedsiębiorcze studentów. Wyniki badań. Zeszyty Naukowe Uniwersytetu Szczecińskiego, 408, Prace Katedry Mikroekonomii, 10, 95-109.

Borowiec, M. (2008). Rola szkolnictwa wyższego w procesie kształtowania gospodarki opartej na wiedzy. Przedsiębiorczość - Edukacja, 4, 24-36.

Borowiec, M. (2011). Zmiany kierunków kształcenia akademickiego w Polsce. Prace Komisji Geografii Przemystu Polskiego Towarzystwa Geograficznego, 18, 9-22.

Borowiec, M., Rachwał T. (2011). Kształtowanie postaw przedsiębiorczych na lekcjach geografii wyzwaniem edukacyjnym w procesach globalizacji. Przedsiębiorczość - Edukacja, 7, 321-332.

Buchner-Jeziorska, A. (2008). Absolwenci szkół wyższych na rynku pracy (lata 1990-2006). W: B. Minkiewicz, P. Błędowski (red.), Absolwenci SGH na rynku pracy, Warszawa: Wyd. SGH, 11-23.

Buchner-Jeziorska, A., (2011). Studia wyższe - bez szans na sukces?! Acta Universitatis. Folia Sociologica, 39, 17-31.

CBOS. (2009). Aspiracje i motywacje edukacyjne Polaków w latach 1993-2009. Warszawa: CBOS. Pozyskano z: http://www.cbos.pl/SPISKOM.POL/2009/K_070 09.PDF.

Czerepaniak-Walczak, M. (2010). Uniwersytet - instytucja naukowo-edukacyjna czy przedsiębiorstwo? Szkoła wyższa w procesie zmiany. W: J. Piekarski, D. Urbaniak-Zając (red.), Innowacje w edukacji akademickiej. Szkolnictwo wyższe w procesie zmiany, Łódź: Wyd. UŁ, 53-64.

Domański, H. (2004). Między komunizmem a rynkiem. Wpływ wykształcenia na zarobki w 27 krajach. W: H. Domański, A. Ostrowska, A. Rychter (red.), Niepokoje polskie, Warszawa: Wyd. IFiS PAN.

Dworak, J. (2011). Wizerunek szkoły wyższej. Zarządzanie szkoła wyższą. Dylematy $i$ wyzwania, Gdańsk: Zeszyty Naukowe WSB, 14, 107-119.

Ernst \& Young Business Advisory, Instytut Badań nad Gospodarką Rynkową. (2009). Diagnoza stanu szkolnictwa wyższego w Polsce. Pozyskano z http://ptbk.mol.uj.edu.pl/download/aktualnosci/akt.diagnoza.pdf.

Gębski, M. (2009). Wybrane teorie rynku pracy. Miscellanea Oeconomicae, 13 (2), 11.

Giermanowska, E., Racław-Markowska, M. (2003). Społeczności lokalne wobec problemu bezrobocia młodzieży. Warszawa: ISP.

GUS. (1990-2010). Roczniki Statystyczne Rzeczpospolitej Polskiej 1990-2010. Warszawa.

GUS. (2000-2011). Bezrobocie rejestrowane w Polsce z lat 1999-2010, Warszawa.

GUS. (2003-2011). Kwartalna informacja o aktywności ekonomicznej ludności 2003-2012, Warszawa.

GUS. (2004-2010). Szkoty wyższe i ich finanse 2004-2010, Warszawa.

GUS. (2012). Bezrobocie rejestrowane I kwartat 2012 rok, Warszawa. 
Hennemann, S., Liefner I. (2010). German university education in geography and development: the mismatch between knowledge and competencies required. Journal of Geography in Higher Education, 34 (2), 215-230.

Jakubowska, A., Rosa, A. (2011). Problemy dopasowania oferty kształcenia szkół wyższych do potrzeb rynku pracy w Polsce. Zarządzanie szkoła wyższa. Dylematy $i$ wyzwania, Gdańsk: Zeszyty Naukowe WSB, 14, $29-43$

Jeruszka, U. (2011). Efektywność kształcenia w szkołach wyższych. Polityka Społeczna, 1, 1-7.

Kabaj, M., Jeruszka, U. (2009). Lepsze przygotowanie absolwentów szkół wyższych do potrzeb gospodarki i funkcjonowania na rynku pracy. Warszawa: IPiSS,

Kiersztyn, A. (2011). Racjonalne inwestycje czy złudne nadzieje: nadwyżka wykształcenia na polskim rynku pracy. Polityka Społeczna, 1, 7-14.

Knapińska, M. (2008). Transformacja zasobów pracy w Polsce w latach 1990-2006, Polityka Społeczna, 2, 6-10.

Knapińska, M. (2009). Sytuacja na rynku pracy w Polsce w latach 2000-2007. W: J. Sokołowski (red.), Problemy ekonomii, polityki ekonomicznej i finansów publicznych, Prace Naukowe Uniwersytetu Wrocławskiego, 143-155.

Kobylarek, A. (2004). Sytuacja społeczno-zawodowa absolwentów uniwersytetu na przykładzie Uniwersytetu Wrocławskiego. Toruń: Wyd. A. Marszałek.

Korpysa, J. (2003). Bezrobocie wśród absolwentów szkół wyższych. W: D. Kopycińska (red.), Kapitał ludzki w gospodarce, Szczecin: PTE, 123-133.

Kowalska, I. (2011). Doświadczenie praktyczne nauczycieli akademickich - wyznacznik wizerunku szkoły wyższej. Zarządzanie szkoła wyższą. Dylematy i wyzwania, Gdańsk: Zeszyty Naukowe WSB, 14, 121-138.

Kryńska, E. (2002). Studia i co potem? Bezrobocie wśród absolwentów szkół wyższych, Polityka Społeczna, 5-6, 6-10.

Kryńska, E. (2008). Młodzi ludzie a rynek pracy i edukacja. W: E. Sulima (red.), Rynek pracy a edukacja, Białystok: Wyd. Uniwersytetu Białostockiego.

Kryńska, E. (2011). Absolwenci szkół wyższych na rynku pracy. Oczekiwania i rzeczywistość. W: K. Jędralska, J. Bernais (red.), Kompetencje absolwentów studiów ekonomicznych. Perspektywa biznesu i nauki, Katowice: Prace Naukowe UE, 87-101.

Kukliński, A. (2003). O nowym modelu polityki regionalnej. Studia regionalne i lokalne, 4, 5-14.

Kurek, S., Rachwał, T. (2011). Development of entrepreneurship in ageing populations of The European Union. Procedia. Social and Behavioral Sciences, 19, 397-405.

Leja, K. (2008). Uniwersytet organizacją służącą otoczeniu. W: K. Leja (red.), Społeczna odpowiedzialność uczelni, Gdańsk: Wyd. Politechnika Gdańska, 53-72.

Mikuła-Bączek, E. (2009). Przeobrażenia instytucjonalne a jakość edukacji szczebla wyższego w Polsce w latach 1990-2006. Nierówności Społeczne a Rozwój Gospodarczy, 4, 461-472.

Ministerstwo Pracy i Polityki Społecznej. (2012, 10 października). Zawody deficytowe i nadwyżkowe w I pótroczu 2011 roku. Pozyskane z: http://www.mpips.gov.pl /analizy-i-raporty/raporty-sprawozdania/rynek-pracy/zawody-deficytowe-i-nadwyzkowe/rok-2011/ .

Orczykowska, A. (2006). Szkolnictwo wyższe a wymagania rynku pracy. Nauka i Szkolnictwo Wyższe, 2/28, 49-64.

Osuch, W. (2012). Podstawy przedsiębiorczości w opinii uczniów krakowskich liceów - szanse i oczekiwania. Przedsiębiorczość - Edukacja, 8, 37-47.

Pawson, E., Fournier, E., Haigh, M., Muniz, O., Trafford, J., Vajoczki, S. (2006). Problem-based Learning in Geography: towards critical assessment of its purposes, benefits and risks. Journal of Geography in Higher Education, 30 (1), 103-116.

Piróg, D. (2011a). Graduates of geographical studies on the labour market in the process of transformation in higher education. Prace i Studia Geograficzne, 48, Prace Instytutu Geografii UJK, 18, 161-172.

Piróg, D. (2011b). Usługi edukacyjne na poziomie akademickim w kontekście wymagań rynku pracy. Prace Komisji Geografii Przemystu Polskiego Towarzystwa Geograficznego, 18, 23-36. 
Piróg, D. (2012a). Aspiracje i plany zawodowe młodzieży akademickiej w Polsce na przykładzie studentów geografii. W: A. Dudak, K. Klimkowska, A. Różański (red.), Przygotowanie zawodowe młodych pedagogów, Kraków: Oficyna Wydawnicza Impuls, 125-144.

Piróg, D. (2012b). Changes to the conception of geography curricula within university education in Poland in the 21st century in the face of labour market challenges, European Journal of Geography, 3 (2), 24-41.

Piróg, D. (2012c). Methods for efficiency improvement of geographical studies within the scope of procurement of work by graduates exemplified by solutions applied in Great Britain and in Germany. W: B. Wójtowicz (red.), Natural sciences in educational systems of European countries in the 21st century, Kraków: Wyd. DEHON, 129-141.

Rachwał, T. (2006). Kształtowanie postaw przedsiębiorczych w edukacji szkolnej. W: B. Muchacka (red.), Szkoła w nauce i praktyce edukacyjnej, t. II, Kraków: Oficyna Wydawnicza „Impuls”, Akademii Pedagogicznej w Krakowie, 427-434.

Skórska, A. (2004). Młodzież na rynku pracy w Polsce i w Unii Europejskiej. Poznań: Wyd. WSB.

Sztanderska, U., (red.). (2007). Edukacja dla pracy. Raport o rozwoju społecznym. Polska, Warszawa: UNDP.

Sztanderska, U., Minkiewicz, B., Bąba, M. (2005a). Absolwent na rynku pracy, Forum Akademickie, 6.

Sztanderska, U., Minkiewicz, B., Bąba, M. (2005b). Absolwent na rynku pracy.cz II, Forum Akademickie, 7-8.

Teichler, U. (2011). Bologna - Motor or Stumbling Block for the Mobility and Employability of Graduates? Employability and mobility of Bachelor Graduates in Europe. Key results of the Bologna process, Rotterdam/Boston/Taipei: Sense Publishers, 1-2, 3-41.

Tracz, M. (2006). Rola i znaczenie podstaw przedsiębiorczości w kształceniu ogólnym. Przedsiębiorczość - Edukacja, 2, 222-225.

Zarycki, T. (2009). Kapitał kulturowy - założenia i perspektywy zastosowań teorii Pierre’a Bourdieu. Psychologia Spoleczna, 4, (1-2), 12-25.

Zioło, Z. (2008). Ekonomiczne i społeczne uwarunkowania rozwoju gospodarki opartej na wiedzy. Przedsiębiorczość - Edukacja, 4, 12-23.

Danuta Piróg, dr, Uniwersytet Pedagogiczny im. Komisji Edukacji Narodowej w Krakowie, Instytut Geografii, Zakład Dydaktyki Geografii.

Adiunkt w Instytucie Geografii Uniwersytetu Pedagogicznego w Krakowie Zainteresowania naukowe autorki ogniskują się wokół dwóch nurtów: zróżnicowania kulturowego Europy i tożsamości jej mieszkańców oraz efektywności studiów geograficznych w aspekcie potrzeb rynku pracy. Aktualnie D. Piróg jest kierownikiem projektu badawczego Ministerstwa Nauki i Szkolnictwa Wyższego w zakresie dyscyplin: polityka regionalna, polityka społeczna i demografia pt. „Absolwenci studiów geograficznych na rynku pracy w Polsce i wybranych krajach Unii Europejskiej”.

Danuta Piróg, PhD, Pedagogical University of Cracow, Institute of Geography, Department of Didactics of Geography.

Author is an assistant professor at the Pedagogical University of Cracow (Institute of Geography, Department of Didactics of Geography). Her research interests are focused on intercultural education, European education, practical preparation of students - candidates for the profession of a geography teacher, and the effectiveness of geographical studies in the context of the needs of the labour market. The author currently manages a research grant of the Ministry of Research and Higher Education: 'Graduates of geography studies on the labour market in Poland and in selected European Union countries'.

Adres/Address: Uniwersytet Pedagogiczny im. Komisji Edukacji Narodowej w Krakowie Instytut Geografii, Zakład Dydaktyki Geografii

ul. Podchorążych 2, 30-084 Kraków, Polska e-mail: dbutryn@up.krakow.pl 